\title{
Resistance of Strawberry Cultivars to Crown Rot Caused by Colletotrichum gloeosporioides Isolates from Florida Is Nonspecific
}

\author{
S. J. MacKenzie and D. E. Legard, University of Florida, Gulf Coast Research and Education Center, Wimauma \\ 33598; L. W. Timmer, University of Florida, Citrus Research and Education Center, Lake Alfred 33850; and \\ C. K. Chandler and N. A. Peres, University of Florida, Gulf Coast Research and Education Center, Wimauma 33598
}

\begin{abstract}
MacKenzie, S. J., Legard, D. E., Timmer, L. W., Chandler, C. K., and Peres, N. A. 2006. Resistance of strawberry cultivars to crown rot caused by Colletotrichum gloeosporioides isolates from Florida is nonspecific. Plant Dis. 90:1091-1097.

Isolates of Colletotrichum gloeosporioides from strawberry (Fragaria $\times$ ananassa) and native grape were tested for virulence on strawberry cultivars in field experiments for three seasons. Isolate aggressiveness and cultivar resistance were determined by the proportion of plants killed at a defined time. Each year, four to six isolates were inoculated on four to seven different cultivars, with a subset of isolates and cultivars evaluated again the next season. On the dates that disease was evaluated, incidence ranged from 10 to $84 \%$ for individual cultivars. Cultivar and isolate effects were significant in all three seasons, but there was no significant cultivar by isolate interaction in any season. Thus, resistance to C. gloeosporioides appears to be nonspecific. In the third season, one isolate of Colletotrichum fragariae from strawberry and one from oak were included. There was no significant cultivar by isolate interaction detected for this species, although there were significant differences among cultivars and isolates. When the resistance of cultivars to both species was compared, the rankings of cultivars were similar, but a modest cultivar by species interaction was evident. The cultivar Treasure was more resistant to crown rot caused by either species than any other cultivar tested.
\end{abstract}

Additional keywords: Colletotrichum crown rot, Glomerella cingulata

Colletotrichum crown rot of strawberry (Fragaria $\times$ ananassa Duchesne) can be caused by any of three fungi, Colletotrichum gloeosporioides (teleomorph Glomerella cingulata), C. fragariae, or $C$. acutatum $(17,27)$. The closely related species $C$. fragariae and $C$. gloeosporioides produce a reddish-brown necrosis of crown tissue following infection that causes plants to wilt and collapse (27). Under greenhouse conditions or in summer nurseries, C. fragariae and C. gloeosporioides also may produce necroses on stolons (4), lesions on fruit $(23,26)$, or black leaf spots (25). Although C. acutatum can also cause crown rot (17), disease symptoms in plants infected with this species are distinct from symptoms produced by $C$. fragariae and C. gloeosporioides (38). Also, where $C$. acutatum co-occurs with $C$. gloeosporioides in Florida, C. acutatum is infrequently isolated from diseased crowns (38). Crown rot is a serious disease in subtropical strawberry production regions

Corresponding author: S. J. MacKenzie

E-mail: SMackenzie@ifas.ufl.edu

Current address of D. E. Legard: California Strawberry Commission, Watsonville, CA 95077.

Accepted for publication 25 March 2006.

DOI: 10.1094/PD-90-1091

(C) 2006 The American Phytopathological Society such as those in the southeastern United States since infection by $C$. fragariae and C. gloeosporioides is favored by warm, moist conditions $(30,33)$. Although crown rot is observed in fields during the winter production season, it is most severe in summer nurseries in the southeast and is one of the primary reasons that transplants are produced in temperate regions.

There is some uncertainty regarding the initial occurrence of the closely related pathogens $C$. fragariae and $C$. gloeosporioides in Florida and historically which of these species was responsible for epidemics in the region. C. fragariae was first reported in Florida nurseries by Brooks in 1935 (5). The first description of crown rot caused by $C$. gloeosporioides or its teleomorph Glomerella cingulata was reported in 1984 (26). The isolates in this report were homothallic and thus described as $G$. cingulata. Subsequently, a portion of the historical isolates from Florida previously described as $C$. fragariae were reclassified as $C$. gloeosporioides based on conidial and setal morphology (21). This suggests that $C$. gloeosporioides may have contributed to crown rot epidemics prior to the initial report in 1984, but was misidentified as $C$. fragariae. At least two of the reclassified isolates produced fertile perithecia when grown together in culture, indicating that they were heterothallic (21). Several of the reclassified isolates have been characterized using molecular meth- ods, and in addition to being distinct from C. fragariae isolates, they also appear to be distinct from homothallic isolates of $G$. cingulata $(18,19)$. Currently, C. gloeosporioides is the Colletotrichum sp. most frequently isolated from diseased crowns in Florida (38). The isolates of C. gloeosporioides from diseased crown tissue have diverse genotypes (38) and appear to be from a recombining population (38). They have the Cgl-2 genotype A+T-rich DNA banding pattern of $C$. gloeosporioides isolates originally identified as C. fragariae (18; S. J. MacKenzie, unpublished). The pathogen also appears to have a broad host range, since the population on noncultivated host species growing adjacent to strawberry fields is genetically indistinguishable from that on strawberry and contains isolates pathogenic to strawberry (40).

Previous studies examining variation in strawberry resistance to $C$. fragariae found a broad range of susceptibility among cultivars and aggressiveness among isolates $(14,22,34)$. One study found a significant cultivar by isolate interaction (34). Host resistance studies using homothallic $G$. cingulata isolates were not as conclusive, as they included only two or three isolates $(15,34)$. One study found significant variation in cultivar susceptibility and isolate aggressiveness, and a significant cultivar by isolate interaction (34). In a later study using a different set of isolates, only cultivar susceptibility varied (15). For $C$. $a c u$ tatum, a specific interaction between strawberry cultivars and isolates was observed (15). A single dominant gene appears to be responsible for this interaction (16), with isolates having either an incompatible reaction with cultivars carrying this gene or an intermediate degree of compatibility (15). Assays used to evaluate resistance to $C$. fragariae and $C$. acutatum were based on symptom development on petioles or foliage and did not focus on the ability of plants to resist necrosis of crown tissue. Variation in cultivar susceptibility to C. gloeosporioides isolates from Florida has not been investigated.

In this study, we investigated the levels of resistance to crown rot caused by $C$. gloeosporioides in cultivars commonly grown in Florida as well as the patterns of virulence and aggressiveness among $C$. gloeosporioides isolates under field conditions. This study generated information 
useful to breeders in terms of the mechanism and sources of resistance to crown rot caused by $C$. gloeosporioides. This information is also valuable to growers deciding which cultivars to plant and from which nursery locations to purchase plants since losses due to crown rot would be especially severe for susceptible cultivars propagated in local Florida nurseries where the disease is most prevalent.

\section{MATERIALS AND METHODS}

Plant materials and cultivation. Four to seven cultivars were selected from those commercially available as leaf-on, bareroot transplants imported from Canada at the beginning of the 2001-2002, 2002-2003, and 2003-2004 seasons. The cultivars used included the standard cultivars in the industry, several new cultivars, and an advanced selection from the Florida Agricultural Experiment Station breeding program. The cultivars Aromas, Camarosa, Gaviota, and Camino Real were developed at the University of California; 'Carmine', 'Earlibrite', 'Strawberry Festival', 'Sweet Charlie', and FL 99-164 are cultivars or selections developed at the University of Florida. The cultivar Treasure is from J \& P Research in Naples, FL. The cultivar Camarosa was previously shown to be susceptible to crown rot and was included as a positive control for all three seasons (38).

Plants were grown on raised, plastic mulch-covered beds $71 \mathrm{~cm}$ wide, $15 \mathrm{~cm}$ high at the edge, and $18 \mathrm{~cm}$ high in the center. Each bed contained two rows of strawberry plants with $30.5-\mathrm{cm}$ spacing between rows and $38-\mathrm{cm}$ spacing between plants within the rows. The distance between bed centers was $1.22 \mathrm{~m}$. Before planting, the beds were fumigated with methyl bromide/chloropicrin $(98: 2)$ at 350 $\mathrm{kg} / \mathrm{h}$. Leaf-on, bareroot transplants were set on 18 October for the 2001-2002 season, 16 October for the 2002-2003 season, and 29 October for the 2003-2004 season. Plants were overhead irrigated for 10 to 12 days to facilitate establishment. After establishment, water and fertilizer were provided through drip tape. Weekly applica- tions of Captan 80WP (Micro Flo, Memphis, TN; n-trichloromethylthio-4cyclohexene-1,2-dicarboximide) at 4.2 $\mathrm{kg} / \mathrm{ha}$ were begun 2 weeks after plants were inoculated. This fungicide prevents new crown infections without inhibiting the progress of infections already established (J. C. Mertely, unpublished) and was used to prevent inoculum spread from collapsed crowns to adjacent plots. Freeze and frost protection was provided by overhead sprinklers when necessary.

Fungal isolates and inoculation procedure. Strawberry crown isolates were obtained from samples submitted to the diagnostic clinic at the University of Florida Gulf Coast Research and Education Center in Dover. During the 2002-2003 season, an isolate from a lesion on wild grape (Vitis rotundifolia) was included, and an ascospore isolate from a perithecium emerging from a strawberry petiole was included during the 2003-2004 season (Table 1). The isolates were identified as C. gloeosporioides using a species-specific internal transcribed spacer (ITS) region primer and random amplified polymorphic DNA (RAPD) analysis $(38,40)$. Briefly, a species-specific ITS primer that produces a positive polymerase chain reaction (PCR) product from $C$. gloeosporioides or $C$. fragariae template DNA was used for initial species identification. Subsequently, bands from five RAPD primer amplification reactions were scored for each isolate. Based on RAPD banding patterns, $C$. gloeosporioides and $C$. fragariae isolates fell into two distinct clusters. All C. gloeosporioides isolates were in the same cluster, yet had distinct RAPD banding patterns from one another, indicating that they were not vegetatively produced from the same parent strain. Isolates were also obtained from seven cultivars to reduce the chance of over-sampling a race that might be selected for on a specific cultivar. Pathogenicity of isolates to strawberry was confirmed by injecting inoculum into crown tissue of greenhouse-grown strawberry plants prior to being used in field experiments. Four to six C. gloeosporioides isolates were used for inocula- tions each season. Two isolates of $C$. fragariae, one from a strawberry crown and the other from an oak (Quercus sp.) leaf lesion in Lake Alfred, FL, were included in the study during the 2003-2004 season.

Inoculum was prepared from 6- to 8day-old cultures grown under continuous fluorescent light at $24^{\circ} \mathrm{C}$ on potato dextrose agar. Conidial suspensions used for inoculations were prepared in sterile deionized water, filtered through four layers of cheesecloth, and diluted to $5 \times 10^{5}$ conidia/ml. Inoculations were performed by spraying $2 \mathrm{ml}$ of conidial suspension with a hand mister directly into the crown of plants 15 to 17 days after the plants were set in the field. The inoculation date was 2 November 2001 for the 2001-2002 season, 31 October 2002 for the 2002-2003 season, and 15 November 2003 for the 2003 2004 season.

Experimental design and statistical analysis. The experiment was designed as a two-factor complete block. There were four blocks in each experiment. Blocks consisted of a single 73-m bed for the 2001-2002 season or two parallel 73- to 76-m beds for the 2002-2003 and 20032004 seasons. All cultivar-isolate combinations were randomly assigned to 10-plant plots within each block along with one uninoculated plot of each cultivar. After inoculation, the number of collapsed plants within each bed was recorded weekly until the experiment was terminated at the end of the growing season. Experiments were terminated 133 days (15 March 2002) after inoculation for the 2001-2002 season, 148 days (28 March 2003) after inoculation for the 2002-2003 season, and 132 days (26 March 2004) after inoculation for the 2003-2004 season. Data used for statistical analysis was the proportion of plants collapsed in each plot on a specified date transformed to the arcsine square root. The formula for the transformation was arc$\sin \{\operatorname{sqrt}[(y+3 / 8) /(n+3 / 4)]\}$, where $y=$ the number of collapsed plants per plot and $n$ $=$ the total number of plants per plot (1). Data for each season were analyzed separately using PROC MIXED of SAS (SAS institute, Cary, NC). In the analysis using

Table 1. Description of Colletotrichum isolates used to inoculate experiments conducted over three seasons in Dover, FL

\begin{tabular}{|c|c|c|c|c|c|}
\hline Species & $\begin{array}{l}\text { Isolate } \\
\text { designation }\end{array}$ & Host - cultivar & Tissue & $\begin{array}{l}\text { Collection site } \\
\text { (FL) and year }\end{array}$ & Season used \\
\hline \multirow[t]{12}{*}{ C. gloeosporioides } & $95-63 \mathrm{~A}$ & Fragaria $\times$ ananassa Duchesne - Oso Grande & Crown & Dover 1995 & 2001-2002 \\
\hline & $96-15 \mathrm{~A}$ & Fragaria $\times$ ananassa - Oso Grande & Crown & Dover 1996 & 2003-2004 \\
\hline & $96-83 \mathrm{H}$ & Vitis rotundifolia & Leaf lesion & Dover 1996 & $2002-2003$ \\
\hline & $96-83 R$ & Fragaria $\times$ ananassa - Selva & Crown & Dover 1996 & $2002-2003$ \\
\hline & $97-15 \mathrm{~A}$ & Fragaria $\times$ ananassa - Sweet Charlie & Crown & Dover 1997 & $2001-2002$ \\
\hline & $97-45 \mathrm{~A}$ & Fragaria $\times$ ananassa - Camarosa & Crown & Dover 1997 & $2001-2002,2002-2003$ \\
\hline & $97-47 \mathrm{C}$ & Fragaria $\times$ ananassa - Camarosa & Crown & Dover 1997 & $2001-2002$ \\
\hline & $97-63$ & Fragaria $\times$ ananassa - Oso Grande & Crown & Dover 1997 & $2001-2002,2002-2003$ \\
\hline & $98-285$ & Fragaria $\times$ ananassa - Sweet Charlie & Crown & Dover 1998 & $2001-2002,2002-2003$ \\
\hline & $00-59$ & Fragaria $\times$ ananassa - Strawberry Festival & Crown & Dover 2000 & $2002-2003,2003-2004$ \\
\hline & $00-117$ & Fragaria $\times$ ananassa - Rosa Linda & Ascospore - petiole & Dover 2000 & $2003-2004$ \\
\hline & $02-172$ & Fragaria $\times$ ananassa - Gaviota & Crown & Dover 2002 & 2003-2004 \\
\hline \multirow[t]{2}{*}{ C. fragariae } & C-16 & Fragaria $\times$ ananassa - Camarosa & Crown & Dover 2002 & 2003-2004 \\
\hline & $02-135$ & Quercus species & Leaf lesion & Lake Alfred 2002 & 2003-2004 \\
\hline
\end{tabular}


C. gloeosporioides and C. fragariae data alone, "block" was considered a random effect and "cultivar" and "isolate" were considered fixed effects. In the analysis where $C$. gloeosporioides and $C$. fragariae data were combined, "species", "isolate", and "cultivar" were all considered fixed effects with "isolate" nested within "species". Block was considered a random effect. Uninoculated plots were not included in any reported analysis. The risk of type I error $(\alpha)$ was 0.05 for least square means $t$ tests comparing transformed disease incidence between cultivars and was not adjusted for multiple comparisons.

\section{RESULTS}

Visually comparing graphs of plant mortality over time after inoculation with $C$. gloeosporioides revealed that the pattern of symptom development was different during the three seasons (Fig. 1A to C). During the 2001-2002 season, the majority of plants that developed crown rot symptoms did so in the first 55 days after inoculation. For the 2002-2003 season, rapid plant collapse within this time period only occurred for 'Gaviota' and 'Camarosa'. During this season, the rate at which plants developed symptoms slowed between day 50 and day 130 after inoculation. However, unlike the 2001-2002 season in which the progress of symptom development also slowed, there was a spike in plant death late in the season. For the 2003-2004 season, symptoms developed on plants throughout the season for all of the cultivars tested. At each time point, the rankings of plants with respect to susceptibility were approximately the same. However, some cultivars such as Earlibrite in the 2002-2003 season, Strawberry Festival in the 2003-2004 season, and FL 99-164 in the 2003-2004 season initially had relatively low disease incidence that increased at a faster rate relative to other cultivars toward the end of the season. Only 'Camarosa' was examined for susceptibility to $C$. gloeosporioides in all three seasons. At the end of each season, the incidence of plant collapse for this cultivar was consistently high, ranging from 62 to $84 \%$. Plants were inoculated with $C$. fragariae only during the 2003-2004 season (Fig. 1D). During this season, the progress of symptom development on plants inoculated with $C$. fragariae showed a similar pattern to that observed for C. gloeosporioides. Spread of pathogens from sources outside the plots or among plots did not appear to affect results in any of the experiments since disease incidence at the end of the season in the uninoculated control plots ranged from $0 \%$ in $2002-2003$ to $0.12 \%$ in $2003-$ 2004.

Transformed disease incidence data used for statistical analysis were obtained at different time points after inoculation for each season. Data for analysis were taken on 4 January 2002, 28 March 2003, and 19 March 2004. These dates corresponded to 63,148 , and 125 days after inoculation, respectively. On these dates, the absolute value of the difference between the number of plots with $0 \%$ plant mortality and $100 \%$ plant mortality was minimized. This reduced compression bias toward one extreme value or the other ( 0 or $100 \%$ mortality). In addition, on these dates, the number of plots with 0 or $100 \%$ mortality was low and variance among treatment combinations was relatively high. Analysis of data for C. gloeosporioides revealed strong isolate and cultivar effects, but no significant cultivar by isolate interaction in each of the three seasons studied (Table 2; Fig. 2A to C). There
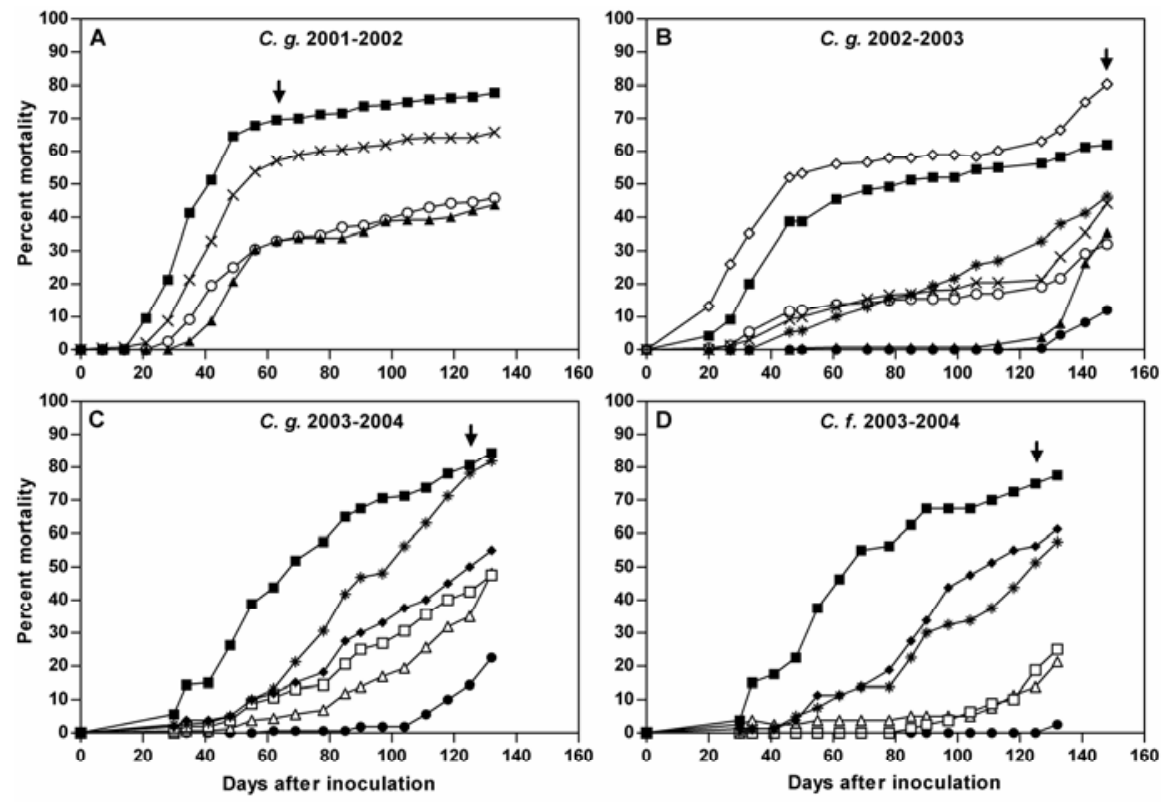

was also a cultivar and isolate effect on disease incidence with $C$. fragariae during the 2003-2004 season, but no significant cultivar by isolate interaction (Table 3, Fig 2D). When the $C$. gloeosporioides and $C$. fragariae data from the 2003-2004 season were combined, in addition to a species, cultivar, and isolate effect on disease incidence, there was also a small but signifi3). This interaction resulted from a change in the rankings of 'Strawberry Festival' and 'Camino Real' across fungal species (Fig. 3). With the exception of this one rank change, disease reactions to isolates of the different Colletotrichum species were very similar. The variance component cant species by cultivar interaction (Table

\begin{tabular}{|c|c|c|c|c|}
\hline $\begin{array}{l}\multimap-\text { Gaviota } \\
\rightarrow-\text { Camarosa }\end{array}$ & $\begin{array}{l}\rightarrow \text { Strawberry Festival } \\
* \text { Aromas }\end{array}$ & $\begin{array}{l}\rightarrow-\text { Camino Real } \\
\rightarrow-\text { Carmine }\end{array}$ & $\begin{array}{l}₫-\text { FL 99-164 } \\
\rightarrow-\text { Earlibrite }\end{array}$ & $\begin{array}{l}\multimap-\text { Sweet Charlie } \\
\rightarrow-\text { Treasure }\end{array}$ \\
\hline
\end{tabular}

Fig. 1. Mean percent mortality for strawberry cultivars calculated at weekly intervals over the course of the growing season using data from all isolates. A, Plants inoculated with Colletotrichum gloeosporioides during the 2001-2002 season. B, Plants inoculated with C. gloeosporioides during the 2002-2003 season. C, Plants inoculated with C. gloeosporioides during the 2003-2004 season. D, Plants inoculated with $C$. fragariae during the 2003-2004 season. Arrows show the time points where disease incidence data were used for statistical analysis.

Table 2. Analysis of variance for three experiments evaluating incidence of crown rot in relation to strawberry cultivar and isolate of Colletotrichum gloeosporioides

\begin{tabular}{llrrr}
\hline Season & Source of variation & df & $\boldsymbol{F}$ value & $\boldsymbol{P} \boldsymbol{F}$ \\
\hline $2001-2002^{\mathrm{x}}$ & Cultivar & 3 & 39.16 & $<0.001$ \\
& Isolate & 5 & 45.04 & $<0.001$ \\
& Cultivar $\times$ isolate & 15 & 1.52 & 0.123 \\
$2002-2003^{\mathrm{y}}$ & 6 & 35.50 & $<0.001$ \\
& Cultivar & 5 & 31.63 & $<0.001$ \\
& Isolate & 30 & 1.34 & 0.134 \\
$2003-2004^{z}$ & Cultivar $\times$ isolate & 5 & 36.66 & $<0.001$ \\
& Cultivar & 3 & 21.08 & $<0.001$ \\
& Isolate & 15 & 0.65 & 0.823 \\
\hline
\end{tabular}

${ }^{\mathrm{x}} F$ values for 2001-2002 season were calculated using a residual variance estimate equal to 0.024 having 69 degrees of freedom.

${ }^{\text {y }} F$ values for $2002-2003$ season were calculated using a residual variance estimate equal to 0.038 having 123 degrees of freedom.

${ }^{\mathrm{z}} \mathrm{F}$ values for $2003-2004$ season were calculated using a residual variance estimate equal to 0.035 having 69 degrees of freedom. 
"block" was not estimated to be greater than zero in any of the experiments $(P>$ 0.05).

All cultivars except 'Gaviota', FL 99164, 'Carmine', and 'Camino Real' were tested in at least two seasons. Eight of the C. gloeosporioides isolates were used for lates (97-45A, 97-63, 98-285, 00-59) were used in two. During the 2001-2002 season, 'Camarosa' was the most susceptible cultivar followed by 'Aromas'. 'Earlibrite' and 'Sweet Charlie' were more resistant and had essentially the same level of susceptibility (Table 4). The ranking of these cultivars for the 2002-2003 season was the same as for 2001-2002, although statistically 'Aromas' could not be separated from 'Earlibrite'. During the 2002-2003 season, 'Treasure', 'Strawberry Festival', and inoculations in one season and four iso-

'Gaviota' also were evaluated. 'Treasure' was more resistant and 'Gaviota' more susceptible than any of the other cultivars examined. 'Strawberry Festival' had an intermediate level of resistance, approximately the same as that of 'Aromas'. During the 2003-2004 season, rankings among cultivars carried over from the previous season remained the same. 'Treasure' was once again the most resistant cultivar and 'Camarosa' was more susceptible than 'Strawberry Festival', although disease ratings for 'Camarosa' and 'Strawberry Festival' were not statistically significantly different from one another during the 2003-2004 season as they were for the 2002-2003 season. During the 2003-2004 season, disease symptoms on 'Strawberry Festival' likely had more time to reach the ratings observed on 'Camarosa'. The three
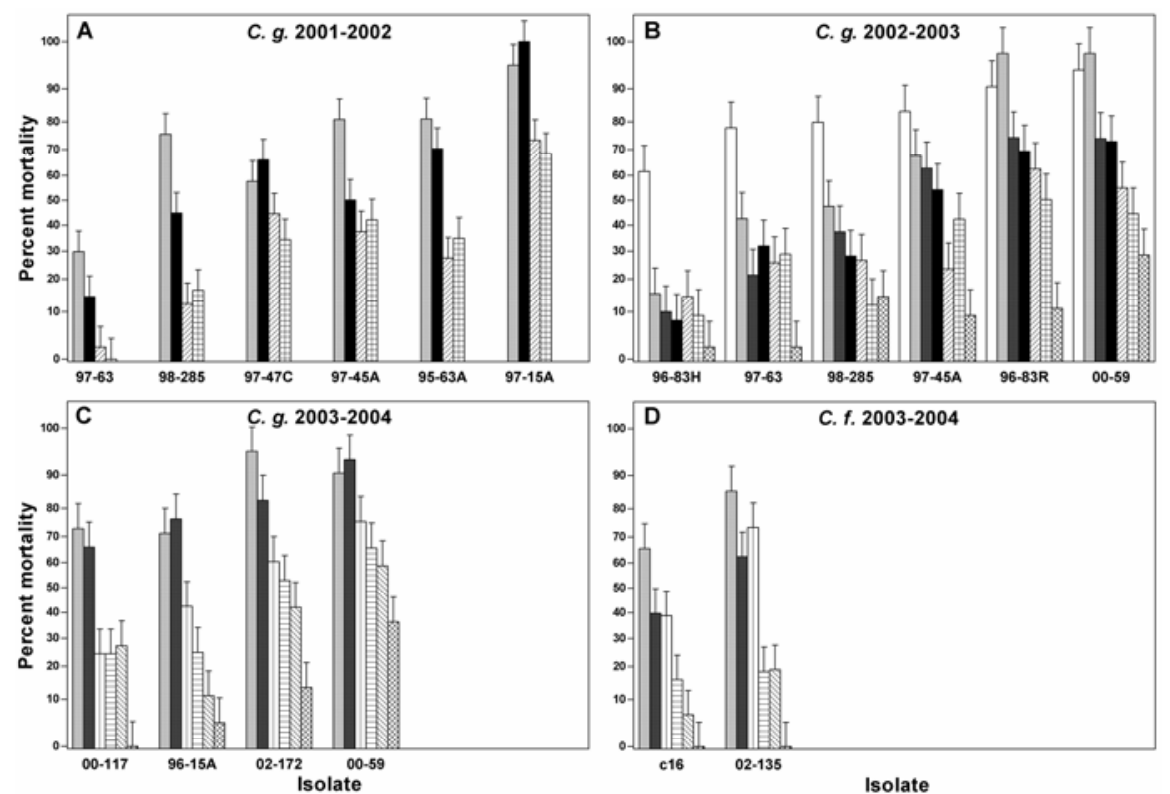

\begin{tabular}{|c|c|c|c|c|}
\hline $\begin{array}{l}\square \text { Gaviota } \\
\square \text { Camarosa }\end{array}$ & $\begin{array}{l}\text { Strawberry Festival } \\
\text { Aromas }\end{array}$ & $\begin{array}{l}\text { एा Camino Real } \\
\rightleftarrows \text { Carmine }\end{array}$ & $\begin{array}{l}\text { FL 99-164 } \\
\text { Earlibrite }\end{array}$ & $\begin{array}{l}\text { 에 Sweet Charlie } \\
\text { Treasure }\end{array}$ \\
\hline
\end{tabular}

Fig. 2. Cultivar by isolate means for transformed disease incidence data calculated on a specific date during or at the end of the season. The $y$-axis shows the position of backtransformed incidences ranging from 0 to $100 \%$ at intervals of $10 \%$. A, Disease incidences calculated for plots 63 days after inoculation with Colletotrichum gloeosporioides during the 2001-2002 growing season. B, 148 days after inoculation with $C$. gloeosporioides during the 2002-2003 growing season. C, 125 days after inoculation with C. gloeosporioides during the 2003-2004 growing season. D, 125 days after inoculation with C. fragariae during the 2003-2004 growing season.

Table 3. Analysis of variance for 2003-2004 experiment evaluating incidence of crown rot in relation to strawberry cultivar and isolate of Colletotrichum fragariae alone or in comparison with C. gloeosporioides

\begin{tabular}{llcrr}
\hline Species included & Source of variation & df & $\boldsymbol{F}$ value & $\boldsymbol{P}>\boldsymbol{F}$ \\
\hline C. fragariae $^{\mathrm{y}}$ & Cultivar & 5 & 24.66 & $<0.001$ \\
& Isolate & 1 & 9.01 & 0.005 \\
& Cultivar $\times$ isolate & 5 & 0.91 & 0.485 \\
C. fragariae and C. gloeosporioides & Species & 1 & 27.10 & $<0.001$ \\
& Cultivar & 5 & 56.91 & $<0.001$ \\
& Isolate $($ species) & 4 & 19.00 & $<0.001$ \\
& Species $\times$ cultivar & 5 & 2.72 & 0.023 \\
\hline
\end{tabular}

${ }^{\text {y }} F$ values for the analysis examining $C$. fragariae only were calculated using a residual variance estimate equal to 0.034 having 33 degrees of freedom.

${ }^{\mathrm{z}} F$ values for the analysis examining both $C$. fragariae and $C$. gloeosporioides were calculated using a residual variance estimate equal to 0.033 having 125 degrees of freedom. genotypes grown only during the 20032004 season, FL 99-164, 'Carmine', and 'Camino Real', were intermediate between the resistant 'Treasure' and the relatively susceptible 'Strawberry Festival' and 'Camarosa'.

During the 2001-2002 season, isolates fell into four groups based on average aggressiveness to the four cultivars tested (Table 5). Isolate 97-15A was the most aggressive and isolates 95-63A, 97-45A, and $97-47 \mathrm{C}$ had relatively high, comparable levels of aggressiveness. Isolates 98285 and 97-63 were not as aggressive, with isolate 97-63 being even less aggressive than 98-285. Isolates $97-45 \mathrm{~A}, 98-285$, and 97-63 were re-evaluated in the 2002-2003 season. These three isolates along with $00-$ 59, 96-83R, and 96-83H also produced four isolate clusters based on aggressiveness. The three isolates from the 20012002 season had intermediate levels of aggressiveness similar to the previous year. The rankings of these isolates with respect to one another also remained the same, although in the second season isolates 98 285 and 97-63 were not significantly different from each other. Isolates 00-59 and 96-83R were highly aggressive, and isolate $96-83 \mathrm{H}$, a nonstrawberry isolate, was the least aggressive isolate examined. For the 2003-2004 season, only isolate 00-59 was re-evaluated. Once again it was a highly aggressive isolate. Other isolates examined fell into two groups, with isolate 02-172 being more aggressive than isolate $96-15 \mathrm{~A}$ and ascospore isolate 00-117. In separate analyses comparing inoculated plots to uninoculated controls, all isolate treatments had significantly more crown rot than controls (data not shown).

Cultivar rankings for resistance to $C$. fragariae were very similar to those for $C$. gloeosporioides during the season that this species was included in the study (Table 4). 'Treasure' was highly resistant to $C$. fragariae; FL 99-164 and 'Carmine' displayed moderate levels of resistance, and 'Strawberry Festival' and 'Camarosa' were

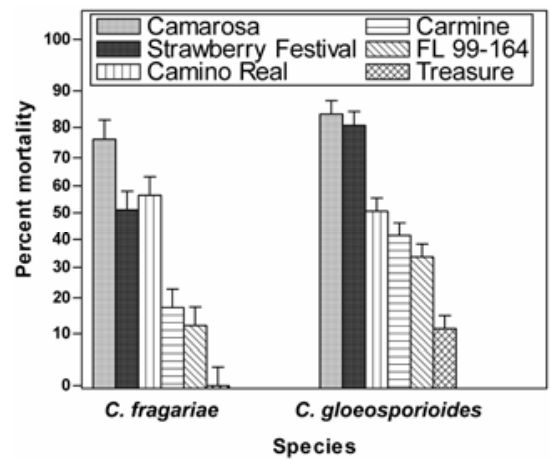

Fig. 3. Cultivar by species means for transformed disease incidences calculated 125 days after inoculation with Colletotrichum fragariae or C. gloeosporioides during the 2003-2004 season. The y-axis shows the position of backtransformed incidences ranging from 0 to $100 \%$ at intervals of $10 \%$. 
relatively susceptible. The rankings only differed in that 'Camino Real' appeared to be more resistant and 'Strawberry Festival' more susceptible to $C$. gloeosporioides than to $C$. fragariae, but not dramatically so. Only two C. fragariae isolates were included in the study. These isolates displayed different levels of aggressiveness: isolate $02-135$, a $C$. fragariae isolate from a nonstrawberry host, was more aggressive than $\mathrm{C}-16$, the isolate from strawberry (Table 5).

\section{DISCUSSION}

Pathogenicity trials conducted over 3 years using 12 distinct $C$. gloeosporioides isolates and 10 strawberry cultivars identified differences in disease resistance among cultivars and differences in aggressiveness among isolates, but failed to identify any cultivar by isolate interactions. A more limited study using two $C$. fragariae isolates inoculated on six strawberry cultivars conducted during the third year identified differences in disease resistance among cultivars and differences in aggressiveness among the isolates, but failed to identify a cultivar by isolate interaction. When cultivar resistance rankings were compared between the two pathogen species, there was a small but significant cultivar by species interaction.

Horizontal resistance is effective against all isolates of a pathogen, whereas vertical resistance is effective against a subset of isolates (39). These terms are synonymous with race-non-specific and race-specific resistance, respectively (3). In pathosystems where race-specific resistance occurs, an incompatible interaction between the host and pathogen often requires a dominant host resistance gene and a dominant pathogen avirulence gene. Such interactions are described by the gene-for-gene hypothesis (20). Race-non-specific resistance is less understood, but is believed to be governed by many host genes that incrementally contribute to the overall resistance of the plant $(32,39)$. Vanderplank proposed using analysis of variance to determine the contribution of race-nonspecific and/or race-specific resistance within a host population against a group of pathogen isolates (39). Absence of a cultivar by isolate interaction is evidence for race-non-specific resistance using this method. A cultivar by isolate interaction suggests that race-specific mechanisms contribute to the resistance observed within the host population, although deviations from additivity could be responsible for the statistical interaction (31). Deviations from additivity result from the scale used to measure resistance, whereas rank changes are consistent with physiological interdependency between the host and isolates. No cultivar by isolate interactions were detected in this study, suggesting that race-non-specific resistance mechanisms are responsible for the differences in resis- tance observed between cultivars. Using transformed percentages taken at a time point in which disease incidence was intermediate effectively reduced interactions attributable to deviations from additivity. This finding may be useful in examining resistance to other wilt diseases where use of arbitrary rating scales or measurements of area under the disease progress curve may produce results in which there are no transformations available to eliminate undesirable scale effects. A drawback of measuring resistance using the proportion of collapsed plants is that the rankings of cultivars could change at different time points after inoculation as resistance may occur at different levels of the infection process. Temporally distinct resistance mechanisms have been demonstrated for Phytophthora palmivora on cacao (28). The first level of resistance, referred to as penetration resistance, was attributed to morphological factors, and the second level of resistance, referred to as postpenetration resistance, impeded tissue invasion by the pathogen after colonization. In the current study, rank changes between cultivars over the course of the season were infrequent and occurred only between cultivars displaying similar levels of resistance, suggesting that sequential deployment of resistance mechanisms had little effect on the evaluation of cultivars. However, the relatively high levels of inoculum used could have saturated structural mechanisms that limit ingress into the host. Similarly, individual isolates within the pathogen population might differ in their ability to overcome plant defenses at different times during and after invasion of tissues. However, like the cultivar resistance rankings, pathogen aggressiveness rankings did not change over the course of the experiment (data not shown).

Table 4. Mean percent plant collapse of cultivars inoculated with Colletotrichum gloeosporioides or $C$. fragariae during three seasons in Dover, FL

\begin{tabular}{|c|c|c|c|c|}
\hline \multirow[b]{3}{*}{ Cultivar } & \multicolumn{4}{|c|}{ Disease incidence $(\%)^{y}$} \\
\hline & \multicolumn{3}{|c|}{ C. gloeosporioides } & \multirow{2}{*}{$\begin{array}{c}\text { C. fragariae } \\
2003-2004\end{array}$} \\
\hline & $2001-2002^{z}$ & $2002-2003$ & 2003-2004 & \\
\hline Treasure & & $10.0 \mathrm{a}$ & $11.3 \mathrm{a}$ & $0.0 \mathrm{a}$ \\
\hline Sweet Charlie & $30.3 \mathrm{a}$ & $29.9 \mathrm{~b}$ & & \\
\hline Earlibrite & $30.7 \mathrm{a}$ & $33.9 \mathrm{bc}$ & & \\
\hline FL 99-164 & & & $33.7 \mathrm{~b}$ & $12.0 \mathrm{~b}$ \\
\hline Carmine & & & $41.5 \mathrm{bc}$ & $17.1 \mathrm{~b}$ \\
\hline Camino Real & & & $50.6 \mathrm{c}$ & $56.4 \mathrm{c}$ \\
\hline Aromas & $59.6 \mathrm{~b}$ & $43.1 \mathrm{~cd}$ & & \\
\hline Strawberry Festival & & $45.9 \mathrm{~d}$ & $80.6 \mathrm{~d}$ & $51.1 \mathrm{c}$ \\
\hline Camarosa & $71.8 \mathrm{c}$ & $64.7 \mathrm{e}$ & $83.8 \mathrm{~d}$ & $76.3 \mathrm{~d}$ \\
\hline Gaviota & & $82.2 \mathrm{f}$ & & \\
\hline
\end{tabular}

${ }^{\text {y }}$ Statistical tests were conducted on mean transformed disease incidences. Reported values were calculated by backtransforming the mean arcsine square root disease incidences for all isolates inoculated on a cultivar.

${ }^{\mathrm{z}}$ Statistical tests only compare means for plants inoculated with the same species within the same season. Means in each column followed by the same letter are not significantly different, least squares means $t$ tests $(P=0.05)$.

Table 5. Mean percent plant collapse for Colletotrichum gloeosporioides or $C$. fragariae isolates used to inoculate strawberry cultivars during three seasons in Dover, FL

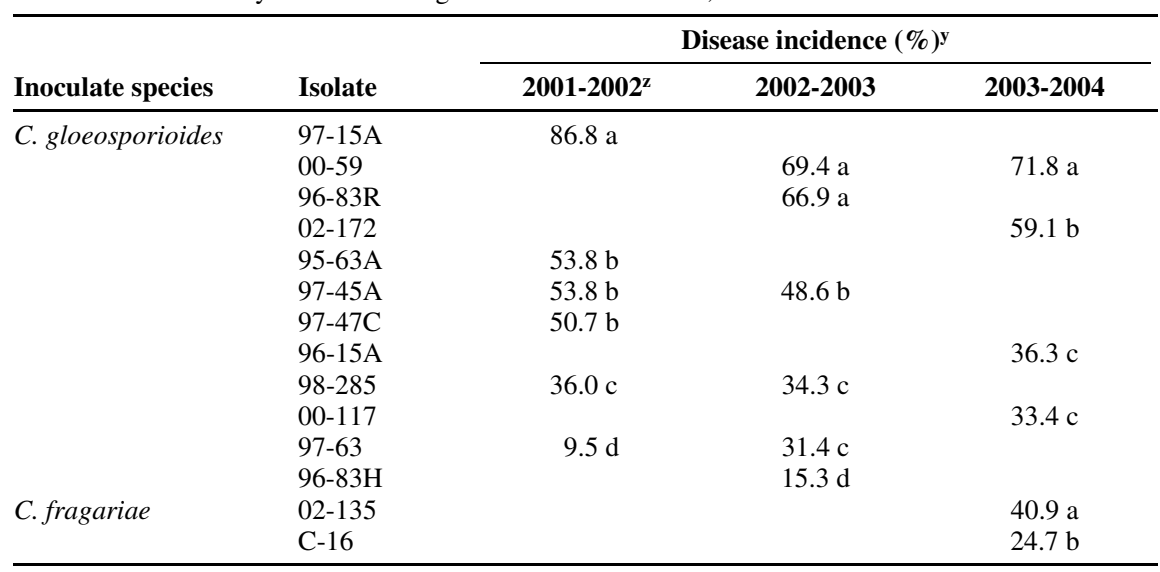

${ }^{y}$ Statistical tests were conducted on mean transformed disease incidences. Reported values were calculated by backtransforming the mean arcsine square root disease incidences for all cultivars inoculated with an isolate.

${ }^{\mathrm{z}}$ Statistical tests only compare means for isolates of the same species within the same season. Means in each column followed by the same letter are not significantly different, least squares means $t$ tests $(P=0.05)$. 
During the 2001-2002 season, crown rot symptoms appeared to progress faster early in the season than they did in the 2002-2003 or 2003-2004 seasons. This was probably due to higher early-season temperatures since the average daily temperature in December was $18.3^{\circ} \mathrm{C}, 3.7^{\circ} \mathrm{C}$ higher than it was in the other seasons. The mean daily temperature of $11.6^{\circ} \mathrm{C}$ in January of the $2002-2003$ season was $2.5^{\circ} \mathrm{C}$ lower than the mean temperature during January for the other two seasons and may have slowed down symptom development during this time period.

In a previous study examining resistance to $G$. cingulata and $C$. fragariae in strawberry, cultivar by isolate interactions were observed (34). The $G$. cingulata isolates used in that study were homothallic and therefore likely to have been from a genetically distinct subpopulation within the same taxonomic group as those used in the current study. Also, in that study, it is conceivable that scale effects produced by the severity rating system used to evaluate disease accounted for the interaction. However, the interactions may also have been due to use of cultivars not included in the current study. Commercial cultivars shipped from Canada were used to obtain the relatively large number of plants free of crown rot required for the experiment. A disadvantage of using these cultivars for studying mechanisms of resistance was that some of them were closely related, restricting the diversity of the germ plasm evaluated. For example, 'Earlibrite' (11) and 'Strawberry Festival' (12) share 'Rosa Linda' as a parent, and 'Strawberry Festival' (12) and 'Treasure' (U.S. Plant Patent 12,414) share 'Oso Grande' as a parent. Nevertheless, a great deal of variance in resistance was observed among them. It is also conceivable that strains with virulence patterns distinct from the isolates tested exist, but were not sampled due to their low frequency within the population. Use of isolates from different cultivars or hosts each with distinct RAPD banding patterns should have enhanced the probability of finding these strains; however, given the high variability of C. gloeosporioides (38) and the fact that only two $C$. fragariae isolates were used in the current study, we cannot conclude that a more extensive sample would not reveal isolates that react with cultivars differently.

A cultivar by isolate interaction for resistance has been demonstrated for $C$. acutatum (15). A single dominant gene (Rca2) appears to be responsible for this interaction (16) and distinguishes two groups of $C$. acutatum, those producing a noncompatible reaction with cultivars having Rca2 (group 2) and those having an intermediate degree of compatibility with cultivars possessing the Rca2 gene (group 1) (15). Although $C$. acutatum is more distantly related to $C$. gloeosporioides than C. fragariae (35) and produces different disease symptoms on strawberry (27), there is evidence that resistance to $C$. $a c u$ tatum, C. fragariae, and G. cingulata is correlated (34). Cultivars at least moderately resistant to fruit rot caused by $C$. acutatum examined in the current study include 'Sweet Charlie' (8), 'Carmine' (10), and 'Earlibrite' (C. K. Chandler, unpublished). 'Sweet Charlie' is field immune to fruit rot, whereas 'Carmine' and 'Earlibrite' are moderately resistant. Although the mechanism of resistance to $C$. acutatum in these cultivars has not been examined, it is likely that these cultivars possess at least one copy of a dominant resistance gene to group $2 C$. acutatum isolates. A dominant resistance gene to this group of isolates was found in 13 of 14 cultivars from the United States and Europe classified as being intermediately susceptible or resistant to anthracnose fruit rot, whereas it only occurred in one of seven cultivars classified as susceptible (16). Also, cultivars such as 'Dover', which is homozygous for the Rca2 gene (16), and 'Sequoia', which is heterozygous for the Rca 2 gene (16), occur in the pedigrees of the three fruit rot resistant cultivars used in the current study (9-11). With the exception of 'Treasure', no cultivar displayed significantly greater resistance to crown rot than 'Sweet Charlie', 'Earlibrite', and 'Carmine', suggesting that major gene resistance to $C$. acutatum could also be effective against $C$. gloeosporioides. The lack of a cultivar by isolate interaction observed with isolates of $C$. gloeosporioides could be due to little variation in a gene product or products in this species homologous to those responsible for the interaction with $C$. acutatum. Also of importance is the fact that 'Treasure' was found to be highly susceptible to anthracnose fruit rot caused by $C$. $a c u$ tatum in field trials conducted over 2 years (C. K. Chandler, unpublished), indicating that genes responsible for resistance to crown rot caused by $C$. gloeosporioides do not necessarily confer resistance to $C$. acutatum.

Race-specific resistance is found most frequently in biotrophic plant-microbe interactions where there is prolonged contact between the pathogen and the living host (20). Colletotrichum species use nutritional strategies ranging from necrotrophy to hemibiotrophy (29). Colletotrichum species such as $C$. orbiculare, $C$. graminicola, $C$. sublineolum, $C$. destructivum, $C$. truncatum, and $C$. linicola are all considered hemibiotrophs, as there is an asymptomatic biotrophic interaction between these species and host cells before the reaction becomes necrotrophic (29). The occurrence of a number of dominant racespecific resistance genes in bean to $C$. lindemuthianum, a member of the $C$. orbiculare species aggregate, suggests that gene-for-gene interactions play an important role in host resistance to these hemibiotrophic pathogens (41). No microscopic studies of strawberry crown invasion by $C$. gloeosporioides have been conducted, although invasion of subtropical fruits $(2,6)$, northern jointvetch (36), and Stylosanthes scabra (37) by C. gloeosporioides has been investigated. On citrus and avocado fruit, $C$. gloeosporioides is a quiescent epiphyte that is able to become necrotrophic upon ripening of the fruit $(2,6)$. On foliage of $S$. scabra and northern jointvetch, $C$. gloeosporioides has a brief biotrophic phase before entering an extended necrotrophic stage $(36,37)$. The evidence for this biotrophic interaction is not nearly as clear as it is for interactions between Colletotrichum spp. commonly referred to as hemibiotrophs and is limited to the occurrence of a spherical vesicle inside an epidermal cell just beneath the appressorium from which infection hyphae emanate. A differential interaction between $S$. scabra cultivars and biotype A C. gloeosporioides isolates has also been demonstrated (37), although a great deal of the variation in resistance among cultivars is due to race-non-specific mechanisms (7). The histopathology of infections caused by the related pathogen, C. fragariae, on strawberry stolons showed that a brief biotrophic phase possibly occurred before the pathogen entered an extended necrotrophic phase (13). The biotrophic phase was less than $12 \mathrm{~h}$, and it was considered a modification of necrotrophy rather than an example of hemibiotrophy. The lack of race-specific resistance observed in the current study suggests that biotrophic interaction between C. gloeosporioides or $C$. fragariae and strawberry is brief and limited. This finding is also consistent with evidence that both of these species infect hosts unrelated to strawberry $(24,40)$.

An isolate of $C$. gloeosporioides from grape, a C. gloeosporioides ascospore isolate from a strawberry petiole, and an isolate of $C$. fragariae from oak were included in this study. The ascospore isolate has a different RAPD profile from other isolates obtained from the same perithecium from which it was isolated, and it only produces fertile perithecia in culture when paired with a second isolate, indicating that it is heterothallic (S. J. MacKenzie, unpublished). In an analysis of RAPD marker data, the ascospore and grape C. gloeosporioides isolates grouped with the $C$. gloeosporioides population from crown tissue and the $C$. fragariae oak isolate grouped with the $C$. fragariae population from strawberry (S. J. MacKenzie, unpublished). The ascospore isolate was one of the least aggressive isolates during 2003-2004, although it was as aggressive as one of the crown rot isolates. During the 2002-2003 season, the grape isolate was less aggressive than the isolates from strawberry crowns. This may result from more aggressive isolates being selected in the $C$. gloeosporioides population on 
strawberry. The $C$. fragariae isolate from oak was more aggressive and had essentially the same virulence pattern as the isolate from strawberry. This is further evidence that $C$. fragariae from strawberry is derived from a population with a very broad host range, since the oak isolate was found $28 \mathrm{~km}$ from any strawberry production area. The only interaction detected was between the species of isolate and cultivar. The interaction was small, and only one rank change occurred between cultivars. Although further studies should be conducted to confirm this finding, it suggests that resistance to $C$. gloeosporioides and $C$. fragariae is positively correlated and that there are also differences in the mechanisms of resistance to these two species.

Information obtained from the current study could improve efficiency of germ plasm screens and aid progenitor selection. For future screens of strawberry plants for resistance to $C$. gloeosporioides isolates from Florida, the absence of a cultivar by isolate interaction suggests that use of numerous isolates is not necessary. Although virulence patterns of the isolate collection used in the current study were the same, there were differences in aggressiveness among isolates. A potentially useful strategy of isolate selection for future screens could employ a combination of isolates with different levels of aggressiveness. An advantage of this strategy is that less aggressive isolates could differentiate between genotypes with low or moderate resistance and aggressive isolates could be used to differentiate resistant cultivars. The study was not designed to determine if resistance in 'Treasure' is controlled by a major gene, however information from the pedigrees of 'Treasure' and 'Strawberry Festival' suggest that it may be. Both 'Treasure' and 'Strawberry Festival' share 'Oso Grande' as a parent (12; U.S. Plant Patent 12,414), yet have very different levels of resistance to crown rot. The occurrence of a major gene or genes for resistance to crown rot in 'Treasure' could account for this difference. Appropriate crosses would need to be conducted to confirm that this is the case. Also, because 'Treasure' is not resistant to fruit rot caused by $C$. acutatum, the resistance is probably unique from resistance conferred by the Rca 2 gene. That at least some disease was observed in all of the cultivars tested has important implications for disease control strategies. Given that $C$. gloeosporioides is broadly distributed on multiple hosts in Florida (40), at least a portion of plants of any cultivar are likely to become infected, with crowns infected by more aggressive isolates showing symptoms. Use of resistant cultivars would likely reduce spread among strawberry plants.
LITERATURE CITED

1. Anscombe, F. J. 1948. The transformation of poisson, binomial and negative-binomial data. Biometrika 35:246-254.

2. Binhamini, N., and Schiffmann-Nadel, M. 1972. Latent infection in avocado fruit due to Colletotrichum gloeosporioides. Phytopathology 62:592-594.

3. Bos, L., and Parlevliet, J. E. 1995. Concepts and terminology on plant/pest relationships: Toward consensus in plant pathology and crop protection. Annu. Rev. Phytopathol. 33:69102.

4. Brooks, A. N. 1931. Anthracnose of strawberry caused by Colletotrichum fragariae, n. sp. Phytopathology 21:739-744.

5. Brooks, A. N. 1935. Anthracnose and wilt of strawberry caused by Colletotrichum fragariae. (Abstr.) Phytopathology 25:973-974.

6. Brown, G. E. 1975. Factors affecting postharvest development of Colletotrichum gloeosporioides in citrus fruits. Phytopathology 65:404-409.

7. Chakroborty, S., Cameron, D. F., Irwin, J. A. G., and Edye, L. A. 1988. Quantitatively expressed resistance to anthracnose (Colletotrichum gloeosporioides) in Stylosanthes scabra. Plant Pathol. 37:529-537.

8. Chandler, C. K. 2005. 'Sweet Charlie' strawberry. J. Am. Pomolog. Soc. 59:67.

9. Chandler, C. K., Albregts, E. E., and Howard, C. M. 1997. 'Sweet Charlie' strawberry. HortScience 32:1132-1133.

10. Chandler, C. K., Legard, D. E., Crocker, T. E., and Sims, C. A. 2004. 'Carmine' strawberry. HortScience 39:1496-1497.

11. Chandler, C. K., Legard, D. E., Dunigan, D. D., Crocker, T. E., and Sims, C. A. 2000. 'Earlibrite' strawberry. HortScience 35:1363-1365.

12. Chandler, C. K., Legard, D. E., Dunigan, D. D., Crocker, T. E., and Sims, C. A. 2000. 'Strawberry Festival' strawberry. HortScience 35:1366-1367.

13. Curry, K. J., Abril, M., Avant, J. B., and Smith, B. J. 2002. Strawberry anthracnose: Histopathology of Colletotrichum acutatum and $C$. fragariae. Phytopathology 92:1055-1063.

14. Delp, B. R., and Milholland, R. D. 1981. Susceptibility of strawberry cultivars and related species to Colletotrichum fragariae. Plant Dis. 65:421-423.

15. Denoyes, B., and Baudry, A. 1995. Species identification and pathogenicity study of French Colletotrichum strains isolated from strawberry using morphological and cultural characteristics. Phytopathology 85:53-57.

16. Denoyes-Rothan, B., Guérin, G., LerceteauKöhler, E., and Risser, G. 2005. Inheritance of resistance to Colletotrichum acutatum in Fragaria $\times$ ananassa. Phytopathology 95:405412.

17. Freeman, S., and Katan, T. 1997. Identification of Colletotrichum species responsible for anthracnose and root necrosis of strawberry in Israel. Phytopathology 87:516-521.

18. Freeman, S., Phan, M., and Rodriquez, R. J. 1993. Molecular genotyping of Colletotrichum species based on arbitrarily primed PCR, A + T rich DNA, and nuclear DNA analysis. Exp. Mycol. 17:309-322.

19. Freeman, S., and Rodriquez, R. J. 1995. Differentiation of Colletotrichum species responsible for anthracnose of strawberry by arbitrarily primed PCR. Mycol. Res. 99:501-504.

20. Gabriel, D. W. 1999. Why do pathogens carry avirulence genes? Physiol. Mol. Plant Pathol. 55:205-214.

21. Gunnell, P. S., and Gubler, W. D. 1992. Taxonomy and morphology of Colletotrichum species pathogenic to strawberry. Mycologia 84:157-165.

22. Horn, N. L., Burnside, K. R., and Carver, R. B. 1972. Control of the crown rot phase of straw- berry anthracnose through sanitation, breeding for resistance, and benomyl. Plant Dis. Rep. 56:515-519.

23. Howard, C. M. 1972. A strawberry fruit rot caused by Colletotrichum fragariae. Phytopathology 63:600-602.

24. Howard, C. M., and Albregts, E. E. 1973 Cassia obtusifola, a possible reservoir for inoculum of Colletotrichum fragariae. Phytopathology 63:533-534.

25. Howard, C. M., and Albregts, E. E. 1983 Black leaf spot phase of strawberry anthracnose caused by Colletotrichum gloeosporioides $(=C$. fragariae $)$ Plant Dis. 67:1144-1146.

26. Howard, C. M., and Albregts, E. E. 1984. Anthracnose of strawberry fruit caused by Glomerella cingulata in Florida. Plant Dis. 68:824-825

27. Howard, C. M., Maas, J. L., Chandler, C. K., and Albregts, E. E. 1992. Anthracnose of strawberry caused by the Colletotrichum complex in Florida. Plant Dis. 68:976-981.

28. Iwaro, A. D., Umaharan, P., and Sreenivasan, T. N. 1997. Inheritance of foliar resistance to Phytophthora palmivora (Butler) Butler in cacao (Theobroma cacao L.). Euphytica 96:377383.

29. Latunde-Dada, A. O. 2001. Colletotrichum: Tales of forcible entry, stealth, transient confinement and breakout. Mol. Plant Pathol. 2:187-198.

30. Mori, T. 1998. Effects of temperature as the selection pressure for resistance to anthracnose crown rot (Glomerella cingulata Spaulding et Schrenk) of young strawberry seedlings. J Jpn. Soc. Hortic. Sci. 67:934-938.

31. Parlevliet, J. E. 1976. Evaluation of the concept of horizontal resistance in the barley/Puccinia hordei host-pathogen relationship. Phytopathology 66:494-497.

32. Parlevliet, J. E., and Zadoks, J. C. 1977. The integrated concept of disease resistance; a new view including horizontal and vertical resistance in plants. Euphytica 26:5-21.

33. Smith, B. J., and Black, L. L. 1987. Resistance of strawberry plants to Colletotrichum fragariae affected by environmental conditions. Plant Dis. 71:834-837.

34. Smith, B. J., and Black, L. L. 1990. Morphological, cultural, and pathogenic variation among Colletotrichum species isolated from strawberry. Plant Dis. 74:69-76.

35. Sreenivasaprasad, S., Brown, A. E., and Mills, P. R. 1992. DNA sequence variation and interrelationships among Colletotrichum species causing strawberry anthracnose. Physiol. Mol. Plant Pathol. 41:265-281.

36. TeBeest, D. O., Templeton, G. E., and Smith, R. J. 1978. Histopathology of Colletotrichum gloeosporioides f. sp. aeschynomene on northern jointvetch. Phytopathology 68:1271-1275.

37. Trevorrow, P. R., and Irwin, J. A. G. 1988. Histopathology of compatible and incompatible interactions between Colletotrichum gloeosporioides and Stylosanthes scabra. Trans. Br. Mycol. Soc. 90:421-429.

38. Ureña-Padilla, A. R., MacKenzie, S. J., Bowen, B. W., and Legard, D. E. 2002. Etiology and population genetics of Colletotrichum spp. causing crown rot and fruit rot of strawberry. Phytopathology 92:1245-1252.

39. Vanderplank, J. E. 1968. Disease Resistance in Plants. Academic Press, New York.

40. Xiao, C. L., MacKenzie, S. J., and Legard, D. E. 2004. Genetic and pathogenic analyses of Colletotrichum gloeosporioides isolates from strawberry and noncultivated hosts. Phytopathology 94:446-453.

41. Young, R. A., and Kelly, J. D. 1996. Characterization of the genetic resistance to Colletotrichum lindemuthianum in common bean differential cultivars. Plant Dis. 80:650-654. 